\title{
Effects of Consecutive Streptomycin and Kasugamycin Applications on Epiphytic Bacteria in the Apple Phyllosphere
}

\author{
K. A. Tancos and K. D. Cox, Department of Plant Pathology and Plant-Microbe Biology, New York State Agricultural Experiment Station, \\ Cornell University, Geneva NY 14456
}

\begin{abstract}
Antibiotic applications are essential for fire blight management in the eastern United States. Recently, streptomycin-resistant Erwinia amylovora strains were found in New York. There are growing concerns that streptomycin resistance may develop from postbloom streptomycin applications in local orchards. Our goal was to investigate the impacts of increasing streptomycin and kasugamycin applications on bacterial epiphyte community composition and antibiotic resistance in the phyllosphere of 'Idared' apple plantings in 2014 and 2015. Rinsate samples from leaves treated with $0,3,5$, and 10 applications of streptomycin and kasugamycin were collected to isolate, enumerate, and identify

epiphytic bacterial species. The majority of isolated epiphytic bacteria were identified as Pantoea agglomerans and fluorescent Pseudomonas spp., whereas E. amylovora was rarely found. Overall, postbloom streptomycin use did not result in an increased recovery of streptomycinresistant E. amylovora. However, other streptomycin-resistant epiphytes (P. agglomerans and Pseudomonas spp.) did increase with increasing streptomycin applications. Increasing kasugamycin applications reduced the overall number and percentage of streptomycin-resistant epiphytes in the phyllosphere, which has important implications regarding the use of kasugamycin in orchards where streptomycin resistance is a concern.
\end{abstract}

Erwinia amylovora is a phytopathogenic bacterium that causes fire blight, a disease of rosaceous plant species that is especially devastating in apple and pear, which leads to substantial production losses in the United States annually (Vanneste 2000). During bloom, E. amylovora infects blossoms, causing blossom blight, which often leads to subsequent infection of shoots and rootstocks (Vanneste 2000). These blighted tissues typically become blackened and may exude bacterial ooze ranging from yellow to red in color (Sundin 2014). Economic losses are due to the loss of blossoms and subsequent fruit, fruit-bearing shoots, and often whole trees. This disease can be especially severe in plantings of moderately to highly susceptible apple cultivars, which are in high commercial demand and are widely planted across the major apple-growing regions of the United States (van der Zwet et al. 2012). In 2008, it was estimated that approximately $50 \%$ of new plantings in New York orchards were planted to susceptible cultivars at densities of over 3,000 trees/ha (Breth 2008).

Fire blight management in the eastern United States relies heavily upon the use of antibiotics in apple orchards, particularly the aminoglycoside antibiotics streptomycin and kasugamycin, which are applied at bloom to protect blossoms from anticipated E. amylovora infection (McGhee and Sundin 2011; Sundin 2014). Streptomycin has been used for fire blight management in the eastern United States for over 50 years (McManus et al. 2002), whereas use of kasugamycin is relatively new, with approval for use in New York apple orchards beginning in 2015 (EPA registration number 66330-404) (McGhee and Sundin 2011). Because streptomycin has a long history of effective use in the northeast and is the most economically sound option, this antibiotic remains the most widely used (van der Zwet et al. 2012). Currently, there are no other viable management alternatives that provide an acceptable level of blossom blight control in the temperate production conditions of the eastern United States (Sundin et al. 2009), making the use of antibiotics, especially streptomycin, imperative for fire blight management.

The emergence of streptomycin-resistant (SmR) E. amylovora in the United States is of great concern due to widespread reliance on

Corresponding author: K. D. Cox; E-mail: kdc33@cornell.edu

Accepted for publication 28 August 2016.

() 2017 The American Phytopathological Society this antibiotic for fire blight control (Moller et al. 1981). SmR E. amylovora was first isolated in the western United States in California in 1972, and in Washington shortly afterward (Coyier and Covey 1975; Miller and Schroth 1972). Currently, SmR E. amylovora is found in several western and midwestern states, including Missouri and Michigan (McManus and Jones 1994). SmR E. amylovora was first isolated in New York in 2002, where SmR isolates were detected in two adjacent orchard sites. Orchard surveys made from 2011 to 2014 led to the discovery of several strains of SmR E. amylovora from individual apple orchards in several western New York counties (Tancos et al. 2016).

In the northeastern United States, the most common resistance mechanism is the presence of the tandem gene pair $\operatorname{str} A / s t r B$, whereas resistance caused by a point mutation in the $r p s L$ gene is relatively rare (Chiou and Jones 1995a,b; Tancos et al. 2016). The gene pair strA/strB codes for streptomycin-modifying enzymes (Chiou and Jones 1995b) and, in E. amylovora, is found on the transposon Tn5393 on the ubiquitous nonconjugative plasmid pEA29 (Chiou and Jones 1993; McGhee et al. 2011; McManus and Jones 1994). Several epiphytic bacteria found in the apple phyllosphere, such as Pseudomonas spp. and Pantoea agglomerans, are known to carry the $s t r A / s t r B$ gene pair on R plasmids (Burr et al.1988, 1993). It is theorized that epiphytes such as $P$. agglomerans, which commonly carries $s t r A / s t r B$ on the transposon Tn5393 on the plasmid pEA34, may be responsible for the transfer of these streptomycin resistance genes to the closely related E. amylovora (Chiou and Jones 1991; McGhee et al. 2011). In order for such an event to occur, selective pressure to maintain populations of SmR P. agglomerans and the presence of epiphytic E. amylovora populations in an orchard is necessary.

The development of SmR E. amylovora has been attributed to streptomycin overuse after bloom to control the shoot blight phase of the disease, although evidence for this is mostly anecdotal. In this context, streptomycin applications are often made to nonbearing trees in the nursery or high-value plantings during early establishment to protect against late-season shoot blight infections. The correlation between historical streptomycin use in apple and pear orchards and the recovery of SmR E. amylovora has been studied (Loper et al. 1991; Yashiro and McManus 2012). However, aside from these studies, the development of resistance following direct application of streptomycin remains largely unexplored, and it is unknown whether $\mathrm{SmR}$ E. amylovora could emerge following excessive postbloom streptomycin applications. If this practice did result in the selection of $\operatorname{SmR} E$. amylovora isolates, it would be due to mutation within local E. amylovora populations or due to the acquisition of horizontally transferred 
streptomycin resistance genes from other environmental bacteria. To bridge the knowledge gap between antibiotic applications and resistance development, we wish to determine the impacts of postbloom streptomycin and kasugamycin applications on the development of antibiotic resistance in bacterial epiphytes in the apple phyllosphere We hypothesize that increasing streptomycin applications would lead to an increased recovery of SmR epiphytic bacteria and perhaps the recovery of SmR E. amylovora. Alternatively, increased kasugamycin applications should not preferentially select for SmR epiphytic bacteria and perhaps lead to the recovery of kasugamycin-resistant epiphytic bacteria.

\section{Materials and Methods}

Antibiotic resistance selection experiments in apple orchards. In 2014 and 2015, antibiotic resistance selection experiments were performed on two plantings of 'Idared' apples on B.9 rootstocks in Geneva NY, which were 15 (orchard 1) and 7 (orchard 2) years old, respectively. A completely randomized design was used for all experiments, with antibiotic treatment schedules consisting of four replicate plots, with single trees surrounded by buffer trees within and across rows to minimize interplot interference. Antibiotic resistance selection experiments focusing on streptomycin applications were conducted in orchards 1 and 2 in both 2014 and 2015, while resistance selection experiments focusing on kasugamycin applications took place in orchard 1 in 2014 and both orchards in 2015. Antibiotic application schedules consisted of weekly streptomycin or kasugamycin applications for 0,3 , 5 , or 10 weeks. These applications were made using the commercial products Agri-Mycin 17 (Nufarm, Morrisville, NC) and Kasumin $2 \mathrm{~L}$ (Arysta LifeScience, Cary, NC) at labeled rates of $241.68 \mathrm{~kg} / \mathrm{ha}$ and $6,473.1 \mathrm{ml} / \mathrm{ha}$, respectively. Applications were made with a Solo 451 gas-powered mist blower calibrated to deliver approximately 935.4 liters/ha, a standard volume for high-density apple plantings in the northeastern United States. Antibiotic applications in orchard 1 began at 80\% bloom in late May 2014 and 2015. Applications in orchard 2 began postbloom in early August 2014 and 2015, during terminal elongation. Such applications were made to represent late-season applications to manage shoot blight in nonbearing plantings.

Collection, enumeration, and morphological identification of common bacterial epiphytes. Upon completion of antibiotic application schedules, 50 healthy and fully expanded leaves were collected randomly from each replicate plot. Leaves were grouped into batches of five for a total of 10 batches for each replicate plot. Each of the five-leaf batches where placed in $10 \mathrm{ml}$ of $20 \%$ glycerol and $1 \times$ phosphate-buffered saline in a sealed Ziploc Bag (SC Johnson, Racine, WI) and sonicated in a Bransonic ultrasonic cleaner (Fisher Scientific, Westminster, MD) for $5 \mathrm{~min}$. Following sonication, rinsate samples were stored at $-20^{\circ} \mathrm{C}$ before analysis. Rinsate samples were spread on Crosse Goodman media (CG) (Crosse and Goodman 1973) and incubated at $28^{\circ} \mathrm{C}$ for $48 \mathrm{~h}$ at appropriate dilutions for visual CFU enumeration. The resulting CFU were enumerated to calculate total epiphytic bacteria collected per treatment. $P$. agglomerans and Pseudomonas spp. were commonly recovered from apple leaves in previous studies; therefore, we chose to begin by identifying these bacteria within rinsate samples (McGhee and Sundin 2011; Yashiro and McManus 2012). A subsample of approximately 100 colonies per replicate plot (tree) were transferred to CG and King's B (KB) (King et al. 1954) media and grown at $28^{\circ} \mathrm{C}$ for $24 \mathrm{~h}$. KB cultures were subjected to UV light exposure to observe fluorescent Pseudomonas spp. Putative fluorescent Pseudomonas spp. colonies on KB medium and putative E. amylovora colonies that displayed characteristic cratering morphology on CG were collected and stored for further identification. Of the remaining colonies not identified as fluorescent pseudomonads or E. amylovora, a subsample of 50 colonies from each replicate plot were stored for further polymerase chain reaction (PCR) identification to estimate the percentage of $P$. agglomerans colonies present in rinsate.

PCR identification of putative Pseudomonas spp., E. amylovora, and P. agglomerans. The identity of putative fluorescent Pseudomonas spp. colonies was confirmed by PCR amplification using previously described $16 \mathrm{~S}$ ribosomal RNA (rRNA) Pseudomonasspecific primers (Widmer et al. 1998). The identity of putative E. amylovora colonies was confirmed by PCR amplification using previously described primers (McManus and Jones 1994) specific to the ubiquitous nonconjugative plasmid pEA29, found only in this bacterium (Bereswill et al. 1992; Chiou and Jones 1993; McGhee and Jones 2000). The identity of putative $P$. agglomerans colonies were identified by PCR amplification with previously described primers targeting the pagR gene (Braun-Kiewnick et al. 2012) (Table 1). PCR was performed in $25-\mu$ l reaction volumes and consisted of $12.3 \mu \mathrm{l}$ of $\mathrm{H}_{2} \mathrm{O}, 5 \mu \mathrm{l}$ of $5 \times$ Green GoTaq Flexi Buffer (Promega Corp., Madison, WI), $1 \mu \mathrm{l}$ of forward primer, $1 \mu \mathrm{l}$ of reverse primer, $0.5 \mu \mathrm{l}$ of $10 \mathrm{mM}$ dNTP mix (Promega Corp.), $2.5 \mu \mathrm{l}$ of $25 \mathrm{mM}$ $\mathrm{MgCl}_{2}$ (Promega Corp.), $0.2 \mu$ l of GoTaq G2 Flexi DNA Polymerase (Promega Corp.), and $2.5 \mu \mathrm{l}$ of bacterial DNA sample. PCR cycling parameters were as follows: $94^{\circ} \mathrm{C}$ for $5 \mathrm{~min}$; followed by 35 cycles of $94^{\circ} \mathrm{C}$ for $30 \mathrm{~s}$, annealing for $30 \mathrm{~s}$, and $72^{\circ} \mathrm{C}$ for $30 \mathrm{~s}$; followed by a final extension at $72{ }^{\circ} \mathrm{C}$ for $7 \mathrm{~min}$. Annealing temperatures for the Pseudomonas spp. 16S rRNA primers, pEA29 primers, and pagR primers were 62,54 , and $56^{\circ} \mathrm{C}$, respectively. The resulting PCR products were separated using gel electrophoresis on a $1 \%$ agarose gel in $0.5 \times$ Tris-acetate-EDTA buffer $(44.5 \mathrm{mM}$ Tris-acetate and $1 \mathrm{mM}$ EDTA, $\mathrm{pH} 8.0$ ) at $90 \mathrm{~V}$ for $60 \mathrm{~min}$. To further confirm identity for each bacterial group, a subset of amplified DNA was purified using a Zymo DNA Clean \& Concentrator kit (Zymo Research, Irvine, CA) and sequenced at the Cornell Biotechnical Resource center in Ithaca, NY using an ABI 3730xl capillary electrophoresis instrument (Applied Biosystems, Waltham, MA).

Screening of bacterial epiphytes for streptomycin and kasugamycin resistance. The colonies selected from rinsate samples for epiphyte enumeration were spot transferred to $\mathrm{CG}$ media amended with streptomycin at $100 \mathrm{ppm}$ (CGS) and CG amended with kasugamycin at $100 \mathrm{ppm}(\mathrm{CGK})$ and incubated at $28^{\circ} \mathrm{C}$ for $48 \mathrm{~h}$. Colonies that grew on CGS were considered SmR, while colonies that showed no growth were considered streptomycin sensitive $(\mathrm{SmS})$. Colonies that did not grow on CGK were considered kasugamycin sensitive.

Table 1. Primers used in this study

\begin{tabular}{|c|c|c|c|}
\hline Target $^{\mathbf{a}}$ & Primer $^{\mathbf{b}}$ & Sequence $\left(5^{\prime}-3^{\prime}\right)$ & Source \\
\hline \multirow[t]{2}{*}{ Pseudomonas spp. 16S rRNA } & Ps-F & GGTCTGAGAGGATGATCAGT & Widmer et al. 1998 \\
\hline & Ps-R & TTACCTCCACCTCGCGGG & $\ldots$ \\
\hline \multirow[t]{2}{*}{ Pantoea agglomerans pag $R$} & PagRrt-F & ACGGTGCGTTCCGCAATA & Braun-Kiewnick et al. 2012 \\
\hline & PagRrt2-R & GGCGCCGGGAAAACATAC & \\
\hline \multirow[t]{2}{*}{ Erwinia amylovora pEA29 } & AJ75 & CGCA TTCACGGCTTCGCAGAT & McManus and Jones 1994 \\
\hline & AJ76 & AACCGCCAGGATAGTCGCATA & $\ldots$ \\
\hline \multirow[t]{2}{*}{ strA } & strA406-F & TGACTGGTTGCCTGTCAGAG & Russo et al. 2008 \\
\hline & strA406-R & CGGTAAGAAGTCGGGATTGA & $\ldots$ \\
\hline \multirow[t]{2}{*}{$s t r B$} & strB403-F & ATCGCTTTGCAGCTTTGTTT & Russo et al. 2008 \\
\hline & strB403-R & CGTTGCTCCTCTTCTCCATC & $\ldots$ \\
\hline
\end{tabular}

\footnotetext{
${ }^{\mathrm{a}}$ Gene or sequence target of the primer set.

${ }^{\mathrm{b}}$ Name of the primer used as given in the original source literature.
} 
Representative subsets of putative SmS and SmR bacterial colonies were collected and stored for further confirmation of the presence or absence of the $s t r A / s t r B$ gene pair. PCR amplification was used to confirm the presence of $s t r A / s t r B$ using primers developed by Russo et al. (2008) (Table 1). PCR amplification and gel electrophoresis followed the previously stated protocol, with the exception of annealing temperatures at $56^{\circ} \mathrm{C}$ for $\operatorname{str} A$ primers and $53^{\circ} \mathrm{C}$ for $\operatorname{str} B$ primers. A representative subsample of five amplified $s t r A$ and $s t r B$ PCR products was purified and sequenced as previously described to confirm the identity of visualized bands.

Data analysis. For each antibiotic resistance selection experiment, the percentage of total CFU was determined for four major bacterial epiphyte groups: Pseudomonas spp. as a whole, P. agglomerans, $E$. amylovora, and other miscellaneous epiphyte species. Similarly, the percentage of total antibiotic-sensitive and -resistant CFU was also determined. From these numbers, the mean percentage of total CFU was determined for each antibiotic application schedule (i.e., 0, 3, 5, and 10 applications). The effect of antibiotic application schedule on mean percentage of total CFU for the four major epiphyte groups was determined using generalized linear mixed models with the GLIMMIX procedure of SAS (v9.4; SAS Institute, Cary, NC). All percentage data were subjected to arcsine square-root transformation prior to analysis to stabilize the variance. Differences in the mean percentage of total CFU for each epiphyte group between antibiotic application schedules were determined using the 'lsmeans' statement of GLIMMIX at the 5\% level of significance (SAS Institute). The effect of antibiotic application schedules on the mean percent SmR CFU was determined using generalized linear mixed models with the GLIMMIX procedure of SAS (v9.4; SAS Institute) and differences in these means between antibiotic treatment programs were determined using the 'lsmeans' statement of GLIMMIX at the $5 \%$ level of significance.

\section{Results}

Enumeration and identification of bacterial epiphytes. $P$. agglomerans and fluorescent Pseudomonas spp. (e.g., Pseudomonas putida, $P$. fluorescens, and $P$. syringae) were the most frequently collected epiphytic bacteria in all orchards in both years of this study. E. amylovora was rarely collected, regardless of application treatment, and was found in less than $0.1 \%$ of rinsate samples. A variety of miscellaneous epiphytic bacteria were also collected throughout this study, including several Pantoea spp. (e.g., Pantoea ananatis), Erwinia spp. (e.g., E. rhapontici), and nonfluorescent Pseudomonas spp.; however, no single bacterial species composed the majority of this category. Miscellaneous epiphytic bacteria made up no more than $20 \%$ of colonies recovered from rinsate for any antibiotic application schedules. Also, in terms of total epiphytic bacteria recovered, the number of applications had no bearing on the CFU/liter for each of three types of epiphytic bacteria (data not shown).

Streptomycin applications significantly $(P<0.0001)$ altered the composition of the epiphytic bacterial community in regards to $P$. agglomerans in the apple phyllosphere. With the exception of orchard 2 in 2015, the percentage of P. agglomerans bacteria isolated from streptomycin-treated trees decreased as application schedules increased from 0 to 10 application in both orchards in 2014 and 2015 (Fig. 1). The percentage of P. agglomerans was only
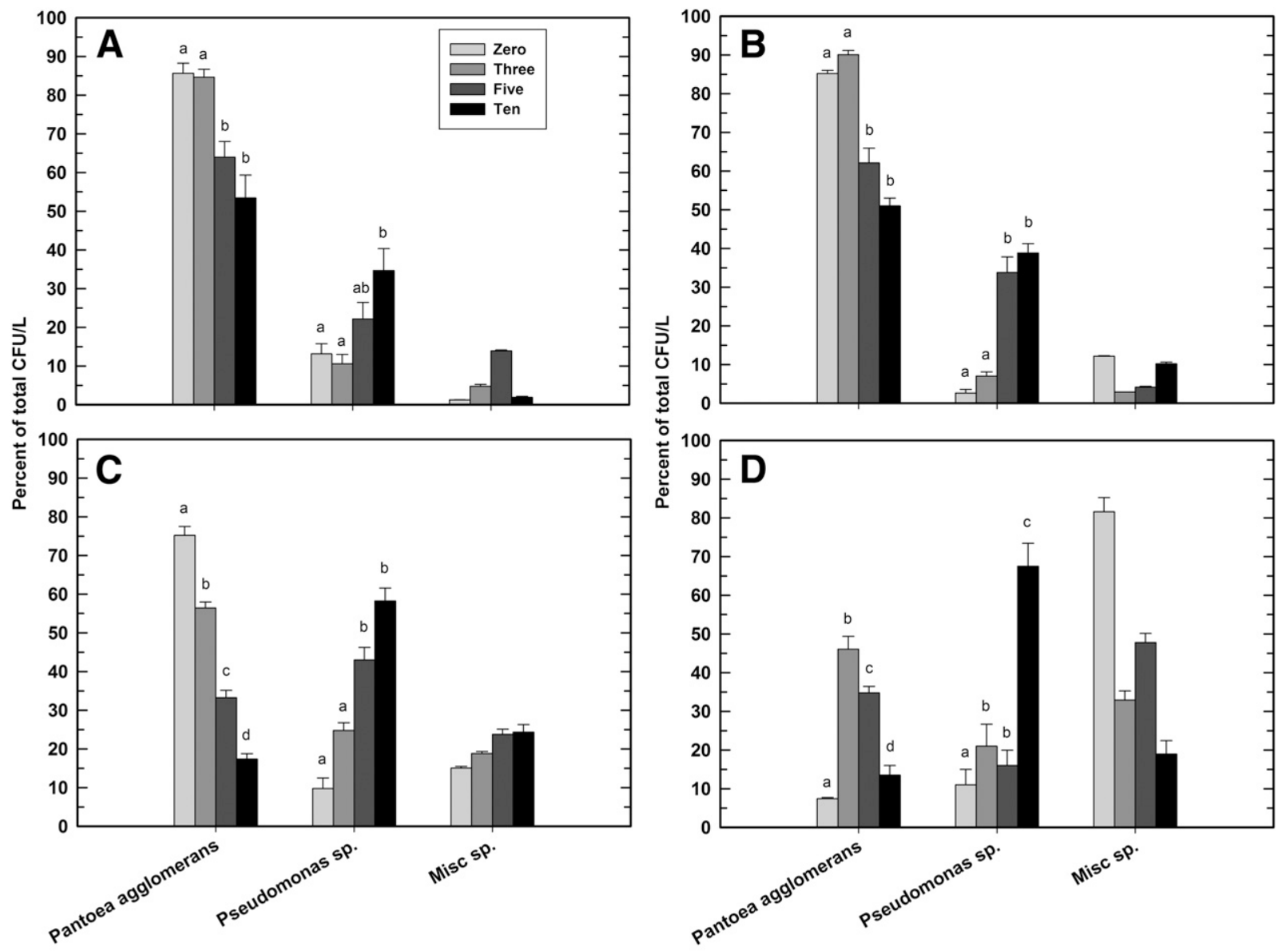

Bacterial Epiphytes

Fig. 1. Percentage of total CFU/liter for Pantoea agglomerans, Pseudomonas spp., and miscellaneous epiphytes for trees receiving $0,3,5$, and 10 applications of streptomycin (Agri-Mycin 17). Values are the mean and standard errors of 10 batches of five leaves with four replicates for A, orchard 1 in 2014 ; B, orchard 2 in 2014 ; C, orchard 1 in 2015; and D, orchard 2 in 2015 . Bars denoted by the same letter are not significantly different as denoted by the 'Ismeans' statement of the GLIMMIX procedure in SAS v9.4 at the $5 \%$ level of significance. 
significantly $(P<0.0001)$ lower on trees receiving 10 applications than trees receiving 0 applications, with the exception of orchard 2 in 2015, where less than $20 \%$ of the total CFU consisted of $P$. agglomerans. Trees receiving 10 streptomycin applications had significantly lower $(P<0.0001)$ percentages of $P$. agglomerans than trees receiving 3 or 5 applications, except for orchard 1 in 2014, where trees receiving 10 applications were statistically equivalent to those receiving 5 applications. For orchard 1 in 2014, P. agglomerans made up 85.6 to $53.4 \%$ of the total epiphytic bacteria isolated from trees as application schedules increased. Orchard 2 in 2014 was similar to orchard 1, with P. agglomerans accounting for 85.2 to $51.0 \%$ of the total isolated epiphytic bacteria as application schedules increased. In 2015, the trends were similar for the two orchards, although the differences in the percentage of $P$. agglomerans recovered seemed to be greater between application schedules. For orchard 1 in 2015, P. agglomerans made up 75.2 to $17.4 \%$ of the total epiphytic bacteria isolated from trees receiving 0 to 10 applications. For orchard 2 in 2015, the percentage of $P$. agglomerans was higher after 3 and 5 applications but was the lowest after 10 applications. In this orchard, P. agglomerans accounted for $7.4,46.1,34.8$, and $13.5 \%$ of the total epiphytic bacteria isolated from trees with $0,3,5$, and 10 applications, respectively.

The percentage of fluorescent Pseudomonas spp. isolated was generally higher from trees receiving higher numbers of streptomycin applications in both orchards in 2014 and 2015 (Fig. 1). However, this trend of increased recovery of Pseudomonas spp. following application schedules with greater numbers of streptomycin applications was only significantly different $(P<0.05)$ between trees receiving 0 and 3 applications and those receiving 5 or 10 applications (Fig. 1). In orchard 1 in 2014, fluorescent Pseudomonas spp. made up 13.1 to $34.7 \%$ of the total epiphytic bacteria isolated from trees as application schedules increased from 0 to 10 . A similar trend was observed in orchard 2 in 2014, because fluorescent Pseudomonas spp. accounted for 2.7 to $38.8 \%$ of the total epiphytic bacteria isolated from trees as application schedules increased from 0 to 10 . Fluorescent Pseudomonas spp. made up 9.8 to 58.3 and 11.0 to $67.5 \%$ of the total epiphytic bacteria isolated from trees receiving 0 to 10 applications in orchards 1 and 2, respectively.

Kasugamycin applications (Kasumin 2L) also significantly $(P<$ 0.0001 ) altered the composition of the epiphytic bacterial community in regards to $P$. agglomerans in the apple phyllosphere (Fig. 2). Overall, the percentage of $P$. agglomerans bacteria isolated from trees treated with kasugamycin was greater as application schedules increased from 0 to 10 in both orchards in 2014 and 2015. Although there were significant differences between the four application schedules depending on the year and orchard, the percentage of $P$. agglomerans bacteria isolated was only consistently significantly $(P<0.0001)$ different between trees receiving 10 applications and trees receiving 0 applications. In 2014, P. agglomerans made up 62.0 to $100 \%$ of the total epiphytic bacteria isolated from trees as application schedules increased from 0 to 10. In 2015, P. agglomerans accounted for 48.0 to 90.8 and 37.2 to $75.0 \%$ of the total epiphytic bacteria isolated from trees as application schedules increased from 0 to 10 in orchards 1 and 2, respectively.

In contrast to the increases observed with $P$. agglomerans, the percentage of fluorescent Pseudomonas spp. isolated from trees treated with kasugamycin decreased with increased antibiotic applications in orchard 1 in 2014 and 2015 (Fig. 2). In this orchard in 2014, fluorescent Pseudomonas spp. made up 24.7 to $0 \%$ of the total epiphytic bacteria isolated from trees receiving 0 to 10 applications (Fig. 2). The percentage of fluorescent Pseudomonas spp. was significantly $(P<0.0001)$ lower between trees receiving schedules with increasingly higher numbers of applications, until none were recovered following 5 and 10 applications. In 2015, fluorescent Pseudomonas spp. accounted for 17.8 to $1.0 \%$ of the total epiphytic bacteria isolated from trees receiving 0 to 10 applications (Fig. 2). Similar to the trend for orchard 1 in 2014, the percentage of fluorescent Pseudomonas spp. was significantly $(P<0.0001)$ lower between trees receiving schedules with higher numbers of applications, with the exception of trees receiving three and five applications that were statistically equivalent $(P>0.05)$. Interestingly, this pattern of decreasing recovery of Pseudomonas spp. following schedules with higher numbers of applications was not observed in orchard 2 in 2015, where this group made up 10.5, 14.3, 4.8, and $10.0 \%$ of the total epiphytic bacteria isolated from trees receiving $0,3,5$, and 10 applications, respectively.

Across both years and orchards, there were no trends observed between application schedule and the percentage of miscellaneous epiphytic bacteria, regardless of the antibiotic used, because many of the
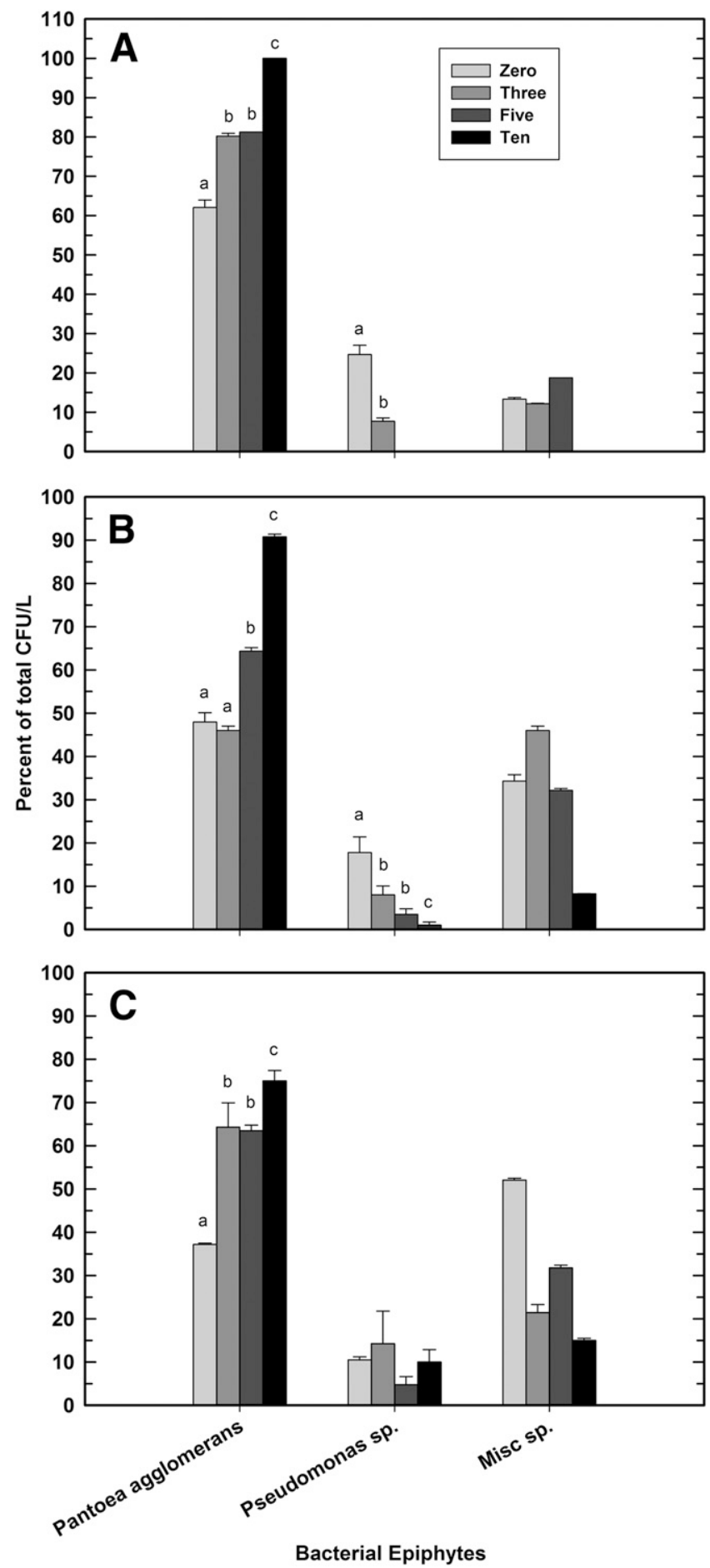

Fig. 2. Percentage of total CFU/liter for Pantoea agglomerans, Pseudomonas spp., and miscellaneous epiphytes for trees receiving $0,3,5$, and 10 applications of kasugamycin (Kasumin 2L). Values are the mean and standard errors of 10 batches of five leaves with four replicates for A, orchard 1 in 2014; B, orchard 1 in 2015; and C, orchard 2 in 2015. Bars denoted by the same letter are not significantly different as denoted by the 'Ismeans' statement of the GLIMMIX procedure in SAS v9.4 at the $5 \%$ level of significance. 
miscellaneous epiphytes were only recovered in a single year or experiment. Even when placed together in the "miscellaneous" category, there were still no significant trends between application schedule and epiphyte recovery for either antibiotic or orchard (Figs. 1 and 2).

Streptomycin and kasugamycin resistance screening of bacterial epiphytes. All isolated epiphytic bacteria displayed no growth on CG medium amended with kasugamycin at 100 ppm; therefore, no kasugamycin-resistant bacteria were recovered in any orchard in any year of this study. SmR epiphytic bacteria were isolated from both orchards and years, regardless of antibiotic used and application schedule. The percentage of SmR bacteria isolated was either greater or remained unaltered following schedules with increasingly higher numbers of streptomycin applications (Table 2). For both orchards in 2014, SmR bacteria accounted for 98.8 to $100 \%$ and 79.5 to $97.0 \%$ of the total epiphytic bacteria isolated from trees receiving 0 to 10 applications. In 2015, a similar trend was observed for both orchards, with SmR bacteria making up 83.3 to 97.5 and 43.3 to $99.3 \%$ of the total epiphytic bacteria isolated from trees receiving 0 to 10 applications. The percent $\mathrm{SmR}$ epiphytes was only significantly higher between trees receiving 0 and 10 applications in orchard 2 in both years $(P<0.0001)$. Interestingly, the percentage of SmR epiphytic bacteria was lower for trees receiving schedules with increasingly higher numbers of kasugamycin applications. For orchard 1 in 2014, SmR bacteria made up 85.3 to $57.7 \%$ of the total epiphytic bacteria isolated from trees receiving 0 to 10 applications. This trend continued in 2015, with SmR epiphytic bacteria accounting for 96.3 to 71.5 and 85.8 to $17.0 \%$ of the total epiphytic bacteria isolated from trees receiving 0 to 10 applications in orchard 1 and 2, respectively. Across all orchards, trees with 10 applications had significantly lower percentages of SmR epiphytic bacteria than trees with 0 applications $(P<0.0001)$ (Table 2$)$. Although there were significant differences between the four application schedules depending on the year and orchard (data not shown), the percentage of SmR epiphytic bacteria isolated was only consistently significantly $(P<$ $0.0001)$ lower for trees receiving 10 applications compared with trees receiving 0 applications.

\section{Discussion}

The frequent recovery of $P$. agglomerans and fluorescent Pseudomonas spp. from all orchards was not surprising, because these bacteria are commonly recovered from apple blossoms and leaves in similar studies of apple phyllosphere bacteria communities (McGhee and Sundin 2011; Yashiro and McManus 2012). Despite the fact that there was active blossom and shoot blight in the orchard (data not shown), it was somewhat surprising to have recovered such a low abundance of E. amylovora (presence in $<0.1 \%$ of rinsate samples). However, the relative rarity of E. amylovora may be not considered an anomaly given that E. amylovora has previously been described as an unsuccessful epiphyte (Bonn 1981; Manceau et al. 1990; Ockey and Thomson 2006). Because no trends were observed regarding the miscellaneous bacteria category, effects of antibiotics on these bacteria were considered minor within orchards used in this study.

The alteration in the epiphytic bacteria community structure, which became evident after the higher streptomycin and kasugamycin application schedules, was not anticipated. It was hypothesized that antibiotic applications would affect the proportion of resistant bacterial epiphytes alone but the changes in relative abundance in the different species was surprising. The decrease in the relative abundance of $P$. agglomerans, regardless of streptomycin resistance, after increasing streptomycin applications has not been reported. Interestingly, $P$. agglomerans (syn. E. herbicola) has been found to be closely related to and often associated with E. amylovora in several studies (Kwon et al. 1997; Riggle and Klos 1972). Although $P$. agglomerans is well known for its competitive inhibition of E. amylovora growth (Vanneste et al. 1992), the decrease in the relative abundance of $P$. agglomerans after five or more applications did not lead to an increase in epiphytic E. amylovora. Nevertheless, it is unknown whether the decrease in the overall $P$. agglomerans population would affect the establishment of E. amylovora populations in the following growing season.

Conversely, schedules with increasing kasugamycin applications resulted in an increase in the relative abundance of $P$. agglomerans. Although the total numbers of epiphytic bacteria declined with increasing kasugamycin applications (data not shown), an increase in the percentage of $P$. agglomerans in the phyllosphere following kasugamycin applications may be disconcerting. P. agglomerans is theorized to be the source from which $E$. amylovora acquired the streptomycin resistance genes $\operatorname{str} A$ and $\operatorname{str} B$ (Chiou and Jones 1993; McGhee and Sundin 2011). If $P$. agglomerans is the predominant epiphytic bacteria in the apple phyllosphere following kasugamycin application, could these bacteria serve as a concentrated source of horizontally transferred streptomycin resistance genes, or even kasugamycin resistance genes, should they develop in the future? However, it is important to note that, although $P$. agglomerans is the prominent epiphyte, the population was reduced by nearly 1,000-fold after 10 kasugamycin applications (data not shown).

Changes in the relative abundance of fluorescent Pseudomonas spp. after kasugamycin applications were also evident. In some cases, fluorescent Pseudomonas spp. were seemingly eliminated from rinsate samples after Kasumin $2 \mathrm{~L}$ applications within a single season. This led us to infer that perhaps differential kasugamycin sensitivity exists among bacterial species within the epiphytic community. Preliminary results have shown that Pseudomonas syringae pv. papulans isolates were not able to grow on CG with kasugamycin concentrations exceeding $50 \mathrm{ppm}$, whereas Pantoea agglomerans isolates were able to grow on $100 \mathrm{ppm}$ (K. D. Cox, unpublished). Kasumin $2 \mathrm{~L}$ is not currently registered for management of tree fruit diseases caused by Pseudomonas spp., such as blister spot (causal agent Pseudomonas syringae pv. papulans) but kasugamycin products

Table 2. Percentage of epiphytes resistant to streptomycin (SmR) after antibiotic applications

\begin{tabular}{|c|c|c|c|c|c|}
\hline \multirow[b]{2}{*}{ Antibiotic, year ${ }^{\mathbf{b}}$} & \multirow[b]{2}{*}{ Orchard } & \multicolumn{4}{|c|}{ Total SmR epiphytes (\%) per application schedule ${ }^{a}$} \\
\hline & & $\mathbf{0}$ & 3 & 5 & 10 \\
\hline \multicolumn{6}{|l|}{ Streptomycin } \\
\hline 2014 & 1 & $98.8 \pm 0.9$ & $98.1 \pm 1.1$ & $100.0 \pm 0.0$ & $100.0 \pm 0.0$ \\
\hline 2014 & 2 & $79.5 \pm 6.5$ & $95.5 \pm 0.6$ & $93.3 \pm 3.5$ & $97.0 \pm 1.2$ \\
\hline 2015 & 1 & $83.3 \pm 6.7$ & $88.3 \pm 3.0$ & $93.5 \pm 2.5$ & $97.5 \pm 1.4$ \\
\hline 2015 & 2 & $43.3 \pm 22.7$ & $96.3 \pm 0.7$ & $95.3 \pm 1.4$ & $99.3 \pm 0.5$ \\
\hline \multicolumn{6}{|l|}{ Kasugamycin } \\
\hline 2014 & 1 & $85.3 \pm 1.3$ & $79.5 \pm 5.4$ & $76.0 \pm 3.2$ & $20.0 \pm 12.2$ \\
\hline 2015 & 1 & $96.3 \pm 1.1$ & $90.8 \pm 1.5$ & $76.8 \pm 2.4$ & $71.5 \pm 3.0$ \\
\hline 2015 & 2 & $85.8 \pm 6.6$ & $76.0 \pm 10.2$ & $73.8 \pm 8.5$ & $17.0 \pm 1.5$ \\
\hline
\end{tabular}

a Number of antibiotic applications in the treatment schedule applied to apple trees $=0,3,5$, or 10. Data shown are mean percentage of total sampled bacterial epiphytes able to grow on Crosse Goodman medium amended with streptomycin at $100 \mathrm{ppm}$. Values are the mean \pm standard errors of 10 batches of five leaves with four replicates.

${ }^{\mathrm{b}}$ Antibiotic applied with streptomycin applications was made using Agri-Mycin 17 and with kasugamycin applications using Kasumin 2L. 
could prove useful in the management of such diseases. Kasumin $2 \mathrm{~L}$ has been shown to provide effective disease control in trials on bacterial speck of tomato ( $P$. syringae pv. tomato), bacterial leaf spot of parsley ( $P$. syringae pv. coriandricola), and bacterial blight of lilac (P. syringae pv. syringae) (Miller et al. 2013; Pscheidt and Bassinette 2011; Vallad et al. 2014)

Regardless of the species, nearly all of the epiphytic bacteria recovered were shown to be SmR. Streptomycin sensitivity was considered rare across all treatments, with less than 5 to $20 \%$ of epiphytic bacteria recovered being $\mathrm{SmS}$. In both orchards receiving streptomycin application schedules over both years, SmR epiphyte recovery was significantly lower $(P<0.05)$ for the trees with no applications than trees that received 3, 5, or 10 applications (Table 2). While we believe that kasugamycin applications should not select for streptomycin resistance, schedules with higher numbers of kasugamycin applications resulted in a lower percentage of SmR bacterial epiphytes recovered. This may imply that there is a fitness cost associated with streptomycin resistance; however, this observation could simply be an artifact resulting from the decrease in total epiphytic bacteria following schedules of increased kasugamycin applications. Further studies are necessary to elucidate the effects of kasugamycin on the stability of streptomycin resistance in epiphytic bacteria.

Although the recovery of SmR bacteria was commonplace, no bacterial colonies from any orchard or treatment were found to grow on kasugamycin-amended CG medium. Schedules with excessive applications (5 and 10 applications) of kasugamycin did not influence the selection or recovery of kasugamycin-resistant epiphytes. This observation leads to the supposition that kasugamycin-resistant bacteria are not present in the phyllosphere in these orchards. Nevertheless, additional sampling from additional sources such as orchard soil would be necessary to eliminate the possibility of kasugamycin-resistant bacteria in these orchards. Kasugamycin-resistant bacteria have been previously isolated in Michigan orchards from soil samples (McGhee and Sundin 2011); however, it is known whether kasugamycin-resistant bacteria in orchard soils or others niches would have an effect on bacterial epiphytes in the phyllosphere.

The changes in community structure observed following antibiotic application schedules were often consistent in both orchards in 2014 and 2015, regardless of whether applications were initiated at $80 \%$ bloom or during shoot elongation. This suggests that the observed changes in the community structure were not simply due to seasonal host development or environmental factors such as temperature or rainfall. The only exception to this would be for percentage of fluorescent Pseudomonas spp. following schedules with higher numbers of kasugamycin applications in orchard 2 in 2015. Because kasugamycin application schedules were only initiated at $80 \%$ bloom in 2014, we would not be able to rule out the potential influence of seasonal factors on the relative abundance of fluorescent Pseudomonas spp. for the 2014 season.

In summary, our results support the point that, even if active fire blight is established in plantings, E. amylovora may not be highly abundant in the epiphytic community of the apple phyllosphere. Also, excessive (5 to 10) streptomycin applications after bloom did not result in recovery of SmR E. amylovora. However, other common bacterial epiphytes such as Pseudomonas spp., which reside on apple foliage and harbor streptomycin resistance genes, became more abundant in trees after receiving increasingly higher numbers of streptomycin applications. Such observations support the recommendation that streptomycin use after bloom should be minimal and reserved for trauma events, even on nursery and nonbearing trees. Finally, kasugamycin applications are highly effective at reducing overall epiphytic bacterial populations, especially in regards to Pseudomonas spp., and may even be effective at reducing the overall abundance of bacterial epiphytes with streptomycin resistance in the phyllosphere.

\section{Acknowledgments}

This research was supported, in part, by funding from state, federal, and institutional funds appropriated to the New York State Agricultural Experiment Station,
New York State IPM, New York State Department of Agriculture \& Markets-Specialty Crop Block Grant Program, and the Apple Research and Development Program. We thank S. Villani, C. Miller, and J. Hagel for their technical assistance.

\section{Literature Cited}

Bereswill, S., Pahl, A., Bellemann, P., Zeller, W., and Geider, K. 1992. Sensitive and species-specific detection of Erwinia amylovora by polymerase chain reaction analysis. Appl. Environ. Microbiol. 58:3522-3526.

Bonn, W. G. 1981. Monitoring of epiphytic Erwinia amylovora and the incidence of fire blight of apple and pear in southwestern Ontario. Acta Hortic. 117:31-36

Braun-Kiewnick, A., Lehmann, A., Rezzonico, F., Wend, C., Smits, T. H. M., and Duffy, B. 2012. Development of species-, strain- and antibiotic biosynthesisspecific quantitative PCR assays for Pantoea agglomerans as tools for biocontrol monitoring. J. Microbiol. Methods 90:315-320.

Breth, D. I. 2008. Managing fire blight in new apple plantings. N. Y. Fruit Q. 16: 9-11.

Burr, T. J., Norelli, J. L., Katz, B., Wilcox, W. F., and Hoying, S. A. 1988. Streptomycin resistance of Pseudomonas syringae pv. papulans in apple orchards and its association with a conjugative plasmid. Phytopathology 78: 410-413.

Burr, T. J., Norelli, J. L., Reid, C. L., Capron, L. K., Nelson, L. S., Aldwinckle, H. S., and Wilcox, W. F. 1993. Streptomycin resistant bacteria associated with fire blight infections. Plant Dis. 77:63-66.

Chiou, C. S., and Jones, A. L. 1991. The analysis of plasmid-mediated streptomycin resistance in Erwinia amylovora. Phytopathology 81:710714.

Chiou, C. S., and Jones, A. L. 1993. Nucleotide-sequence analysis of a transposon (Tn5393) carrying streptomycin resistance genes in Erwinia amylovora and other gram-negative bacteria. J. Bacteriol. 175:732-740.

Chiou, C. S., and Jones, A. L. 1995a. Molecular analysis of high-level streptomycin resistance in Erwinia amylovora. Phytopathology 85:324-328.

Chiou, C. S., and Jones, A. L. 1995b. Expression and identification of the strA-strB gene pair from streptomycin-resistant Erwinia amylovora. Gene 152:47-51.

Coyier, D. L., and Covey, R. P. 1975. Tolerance of Erwinia amylovora to streptomycin sulfate in Oregon and Washington. Plant Dis. Rep. 59: 849-852.

Crosse, J. E., and Goodman, R. N. 1973. A selective medium for and a definitive colony characteristic of Erwinia amylovora. Phytopathology 63:1425-1426.

King, E. O., Ward, M. K., and Raney, D. E. 1954. Two simple media for the demonstration of pyocyanin and fluorescin. J. Lab. Clin. Med. 44:301-307.

Kwon, S., Go, S., Wan, K., Ryu, J., and Jo, J. 1997. Phylogenetic analysis of Erwinia species based on 16S rRNA gene sequences. Int. J. Syst. Bacteriol. 47:1061-1067.

Loper, J. E., Henkels, M. D., Roberts, R. G., Grove, G. G., Willet, M. J., and Smith, T. J. 1991. Evaluation of streptomycin, oxytetracycline, and copper resistance of Erwinia amylovora isolated from pear orchards in Washington State. Plant Dis. 75:287-290.

Manceau, C., Lalande, J., Lachaud, G., Chartier, R., and Paulin, J. 1990. Bacteria colonization of flowers and leaf surfaces of pear trees. Acta Hortic. 273:73-82.

McGhee, G. C., Guasco, J., Bellomo, L. M., Blumer-Schuette, S. E., Shane, W. W., Irish-Brown, A., and Sundin, G. W. 2011. Genetic analysis of streptomycinresistant $\left(\mathrm{Sm}^{\mathrm{R}}\right)$ strains of Erwinia amylovora suggests that dissemination of two genotypes is responsible for the current distribution of $\mathrm{Sm}^{\mathrm{R}}$ E. amylovora in Michigan. Phytopathology 101:182-191.

McGhee, G. C., and Jones, A. L. 2000. Complete nucleotide sequence of ubiquitous plasmid pEA29 from Erwinia amylovora strain Ea88: Gene organization and intraspecies variation. Appl. Environ. Microbiol. 66:48974907.

McGhee, G. C., and Sundin, G. W. 2011. Evaluation of kasugamycin for fire blight management, effect on nontarget bacteria, and assessment of kasugamycin resistance potential in Erwinia amylovora. Phytopathology 101:192-204.

McManus, P. S., and Jones, A. L. 1994. Epidemiology and genetic analysis of streptomycin resistant Erwinia amylovora from Michigan and evaluation of oxytetracycline for control. Phytopathology 84:627-633.

McManus, P. S., Stockwell, V. O., Sundin, G. W., and Jones, A. L. 2002. Antibiotic use in plant agriculture. Annu. Rev. Phytopathol. 40:443-465.

Miller, S. A., Mera, J. R., Xu, X., Baysal-Gurel, F., and Mamiro, D. 2013 Evaluation of bactericides for the control of bacterial leaf spot of parsley, 2013. Online publication. Plant Dis. Manage. Rep. 8:V169. https://www. plantmanagementnetwork.org/pub/trial/pdmr/reports/2014/V169.pdf

Miller, T. D., and Schroth, M. N. 1972. Monitoring the epiphytic population of Erwinia amylovora on pear with a selective medium. Phytopathology 62 1175-1182.

Moller, W., Schroth, M. N., and Thompson, S. V. 1981. The scenario of fire blight and streptomycin resistance. Plant Dis. 65:563-568.

Ockey, S. C., and Thomson, S. V. 2006. Influence of rain on the transient populations of Erwinia amylovora leaf surfaces. Acta Hortic. 704:113-120.

Pscheidt, J. W., and Bassinette, J. P. 2011. Bactericides for management of bacterial blight of lilac, 2011. Online publication. Plant Dis. Manage. Rep. 6 : OT019. https://www.plantmanagementnetwork.org/pub/trial/pdmr/reports/ 2012/OT019.pdf 
Riggle, J. H., and Klos, E. J. 1972. Relationship of Erwinia herbicola to Erwinia amylovora. Can. J. Bot. 50:1077-1083.

Russo, N. L., Burr, T. J., Breth, D. I., and Aldwinckle, H. S. 2008. Isolation of streptomycin-resistant isolates of Erwinia amylovora in New York. Plant Dis. 92:714-718.

Sundin, G. W. 2014. Fire blight. Pages 87-89 in: Compendium of Apple and Pear Diseases and Pests, 2nd ed. T. B. Sutton, H. S. Aldwinckle, A. M. Agnello, and J. F. Walgenbach, eds. American Phytopathological Society, St. Paul, MN.

Sundin, G. W., Werner, N. A., Yoder, K. S., and Aldwinckle, H. S. 2009. Field evaluation of biological control of fire blight in the eastern United States. Plant Dis. 93:386-394.

Tancos, K. A., Villani, S. M., Borejza-Wysocka, E., Kuehne, S., Breth, D., Aldwinckle, H. S., Carol, J., and Cox, K. D. 2016. Prevalence of streptomycin resistant Erwinia amylovora in New York apple orchards. Plant Dis. 100:802-809.

Vallad, G. E., Willis, R., Adkinson, H., Newman, S., Siebert, J., and Riniker, A. 2014. Evaluation of copper and non-copper alternatives for managing bacterial speck of tomato, fall 2014. Online publication. Plant Dis. Manage.
Rep. 9:V107. https://www.plantmanagementnetwork.org/pub/trial/pdmr/ reports/2015/V107.pdf

van der Zwet, T., Orolaza-Halbrendt, N., and Zeller, W. 2012. Pages 37-44 and 305-332 in: Fire Blight History, Biology, and Management. American Phytopathological Society, St. Paul, MN.

Vanneste, J. L., ed. 2000. Fire Blight: The Disease and Its Causative Agent, Erwinia amylovora. CABI Publishing, Oxon, UK.

Vanneste, J. L., Yu, J., and Beer, S. V. 1992. Role of antibiotic production by Erwinia herbicola Eh252 in biological control of Erwinia amylovora. J. Bacteriol. 174:2785-2796.

Widmer, F., Seidler, R. J., Gillevet, P. M., Watrud, L. S., and Di Giovanni, G. D. 1998. A highly selective PCR protocol for detecting 16s rRNA genes of the genus Pseudomonas (sensu stricto) in environmental samples. Appl. Environ. Microbiol. 64:2545-2553.

Yashiro, E., and McManus, P. S. 2012. Effect of streptomycin treatment on bacterial community structure in the apple phyllosphere. PLoS One 7:e37131. 